\title{
ANALISIS HUBUNGAN KEKERINGAN METEOROLOGIS DENGAN KEKERINGAN AGRIKULTURAL DI PULAU LOMBOK MENGGUNAKAN KORELASI PEARSON
}

\author{
Dzikrullah Akbar ${ }^{1}$, Siti Najma Nindya Utami ${ }^{2)}$, Rista Hernandi Virgianto ${ }^{3)}$ \\ ${ }^{13)}$ Sekolah Tinggi Meteorologi Klimatologi dan Geofisika, Jl. Perhubungan I No.5 Pondok \\ Betung, Tangerang Selatan \\ ${ }^{2)}$ Stasiun Pemantau Atmosfer Global, Puncak Vihara Klademak Sorong, Jl. Sungai Remu KM. 8 \\ Malangkedi, Kota Sorong \\ dzikrullah.akbar@stmkg.ac.id, nindyutamy@gmail.com, rista.virgianto@stmkg.ac.id
}

\begin{abstract}
Received:

28/12/2020

One of the disasters can cause losses in various sectors and have an impact on people's lives is drought. Lombok Island is an area with a high risk of drought. The Standardized Precipitation Index (SPI) describes meteorological drought using rainfall as the main parameter. The Normalized Differences Vegetation

Accepted :

$13 / 01 / 2021$ Index (NDVI) describes agricultural drought based on remote sensing. This research aims to determine the relationship between SPI using the reanalysis rainfall data Climate Hazards Group InfraRed Precipitation with Stations

Published :

$X X / 01 / 2021$ (CHIRPS) with observed rainfall (CH Obs) and NDVI at 22 rain observation stations on Lombok Island during the $2001-2018$. The use method is to calculate the Pearson correlation and the significance of SPI with $\mathrm{CH}$ Obs and NDVI. The correlation between SPI with CH Obs and NDVI is positive and significant, respectively 0.31 and 0.21 with p-value $<0.05$. This illustrates that drought monitoring using reanalysis and remote sensing data can be done because it describes the actual drought in the study area. In addition, it can be concluded that the meteorological drought that occurred could have an impact on agricultural drought in the Lombok during $2001-2018$.
\end{abstract}

Keywords: drought, SPI, NDVI, Pearson Correlation

\begin{abstract}
Abstrak
Salah satu bencana yang dapat menyebabkan kerugian di berbagai sektor dan berdampak pada kehidupan masyarakat adalah kekeringan. Pulau Lombok merupakan daerah dengan resiko tinggi mengalami kekeringan. Standardized Precipitation Index (SPI) mendeksripsikan kekeringan meteorologis dengan menjadikan curah hujan sebagai parameter utama. Normalized Differences Vegetation Index (NDVI) menggambarkan kekeringan agrikultural berbasis penginderaan jarak jauh. Penelitian ini mengkaji keterkaitan SPI yang menggunakan masukan curah hujan reanalisis Climate Hazards Group InfraRed Precipitation with Stations (CHIRPS) dengan curah hujan observasi (CH Obs) dan NDVI di 22 titik pos pengamatan hujan di Pulau Lombok selama periode 2001 - 2018. Metode yang digunakan yaitu menghitung korelasi pearson dan signifikansi SPI dengan $\mathrm{CH}$ Obs dan NDVI. Hasilnya menunjukkan bahwa rata-rata korelasi SPI dengan $\mathrm{CH}$ Obs dan NDVI bernilai positif serta signifikan berturut-turut sebesar 0,31 dan 0,21 dengan p-value masing-masing < 0,05. Hal ini memberi gambaran bahwa monitoring kekeringan dengan menggunakan data reanalisis dan penginderaan jarak jauh dapat dilakukan karena menggambarkan kekeringan yang sebenarnya terjadi di wilayah penelitian. Sehingga penelitian ini dapat dijadikan dasar pertimbangan metode monitoring kekeringan di wilayah Lombok. Selain itu, dapat disimpulkan bahwa kekeringan meteorologis yang terjadi dapat berdampak pada kekeringan agrikultural di wilayah Lombok selama $2001-2018$
\end{abstract}

Kata Kunci: kekeringan, SPI, NDVI, Korelasi Pearson 


\section{Pendahuluan}

Kekeringan merupakan bencana alam yang kompleks dan menyebabkan kerugian dalam berbagai sektor kehidupan (Wilhite dan Glantz 1985; Wilhite 1993; Christiawan 2020). Dua diantara beberapa jenis kekeringan tersebut adalah kekeringan meteorologis dan kekeringan agrikultural. Kekeringan meteorologis dimaknai sebagai jumlah curah hujan yang semakin berkurang dibandingkan dengan keadaan normalnya (Lado, 2017). Sedangkan kekeringan agrikultural diartikan sebagai berkurangnya kandungan air dalam tanah sehingga tidak dapat mencukupi kebutuhan air bagi tanaman yang terjadi dalam periode tertentu (Surmaini, 2017). Kekeringan agrikultural biasanya terjadi setelah kekeringan meteorologis.

Untuk menentukan tingkat kekeringan pada suatu daerah secara objektif, dapat dilihat melalui indeks kekeringan. Standardized Precipitation Index (SPI) yang ditemukan oleh McKee dkk. pada tahun 1993 dapat menghitung tingkat keparahan kekeringan pada suatu daerah dengan variabel masukan berupa curah hujan. Hal ini berarti, SPI merupakan salah satu indeks kekeringan untuk menggambarkan tingkat kekeringan meteorologis. Data SPI akan dihitung melalui serangkaian metode memanfaatkan masukan data reanalisis curah hujan Climate Hazards Group InfraRed Precipitation with Stations (CHIRPS).

Karakteristik kekeringan pada suatu wilayah juga dapat dilihat dari jumlah serta tingkat kehijauan tanamannya. Normalized Difference Vegetation Index (NDVI) merupakan salah satu indeks yang dapat dijadikan pertimbangan untuk mendeskripsikan kekeringan agrikultural (Lillesand, dkk., 1987). Data NDVI didapatkan dari penginderaan jarak jauh menggunakan Moderate Resolution Imaging Spectroradiometer (MODIS) yang berada di atas satelit Terra milik National Aeronautics and Space Administration (NASA).

Provinsi Nusa Tenggara Barat (NTB) merupakan salah satu provinsi di Indonesia dengan curah hujan dan ketersediaan air tanah yang rendah. Curah hujan rata-rata tahunan di wilayah NTB hanya mencapai $1900 \mathrm{~mm}$ dan panjang musim hujannya cukup pendek hanya 4 (empat) bulan (Yasin, dkk., 2004). Fakta tersebut sejalan dengan informasi yang dikemukakan oleh Badan Nasional Penanggulangan Bencana (BNPB) pada tahun 2015. Informasi tersebut menyatakan bahwa selama periode tahun 1885 s.d. 2015, kekeringan menjadi bencana terbesar kedua di wilayah Provinsi NTB dengan kejadian sebanyak 96 kali atau setara $25,46 \%$ dari total seluruh kejadian bencana yang dilaporkan. Hal ini 
berarti, wilayah Provinsi NTB memiliki klasifikasi kekeringan dengan kategori tinggi dalam tingkat resiko, kerentanan, dan frekuensi kejadiannya.

Penelitian terkait data reanalisis sebagai inputan SPI dilakukan oleh Zhao, dkk., (2018). Data yang digunakan pada penelitian tersebut merupaka data The Tropical Measuring Mission (TRMM). Hasilnya menunjukkan bahwa data curah hujan TRMM bulanan sangat cocok dengan curah hujan yang observasi, sehingga data penginderaan jauh dan reanalisis ini dapat digunakan untuk menghitung SPI sebagai indeks kekeringan meteorologis secara spasio-temporal di wilayah China pada tahun 1998 - 2014. Keterkaitan SPI dengan NDVI pernah diteliti oleh Jain, dkk., (2010) dengan judul "Penerapan Indeks Meteorologis dan Vegetasi untuk Evaluasi Dampak Kekeringan: Studi Kasus di Rajasthan, India”. Hasilnya menunjukkan bahwa SPI dan NDVI berkorelasi positif dan signifikan dengan NDVI. Selain itu, Dutta, dkk., (2014) juga melakukan penelitian dengan tema yang sama dan menunjukkan bahwa SPI dapat menggambarkan kekeringan agroklimatologis dengan nilai korelasi > 0,75 dengan NDVI.

Berdasarkan uraian di atas, akan diteliti keterkaitan diantara dua indeks kekeringan, yaitu SPI dan NDVI. Selain itu, SPI juga akan dikorelasikan dengan curah hujan observasi ( $\mathrm{CH}$ Obs) untuk mengetahui sejauh mana kekeringan berbasis data reanalisis dapat menggambarkan kekeringan yang sesungguhnya di wilayah penelitian. Analisis korelasi yang akan digunakan adalah Korelasi Pearson. Dengan demikian, peneliti tertarik untuk melakukan kajian tentang "Analisis Hubungan Kekeringan Meteorologis dengan Kekeringan Agrikultural di Pulau Lombok Menggunakan Korelasi Pearson". Kekeringan meteorologis diwakili oleh indeks SPI dan kekeringan agrikultural diwakili oleh indeks NDVI.

Penelitian ini bertujuan untuk mengetahui keterkaitan antara SPI yang diolah dengan masukan data curah hujan reanalisis CHIRPS dengan curah hujan observasi dan NDVI di Pulau Lombok selama periode tahun 2001 s.d. 2018. Penelitian ini diharapkan dapat memberikan manfaat untuk menambah pengetahun tentang gambaran umum kekeringan meteorologis jika dikaitkan dengan kekeringan agroklimatologis di Pulau Lombok. Selain itu, diharapkan penelitian ini dapat memberikan masukan untuk monitoring kekeringan sehingga dampak dari bencana tersebut dapat diminimalisir.

\section{Metode Penelitian}

Penelitian ini menggunakan data dan metode sebagai berikut. 


\subsection{Data dan Lokasi}

Penelitian ini dilakukan di Pulau Lombok, Nusa Tenggara Barat dengan menggunakan data curah hujan observasi (primer), curah hujan reanalisis CHIRPS dan indeks tutupan lahan NDVI (sekunder) di 22 titik pos hujan yang tersebar di 5 Kabupaten/Kota. Pos hujan yang dipilih berdasarkan kriteria kelengkapan data $100 \%$. Secara detail lokasi penelitian disajikan pada gambar berikut ini.

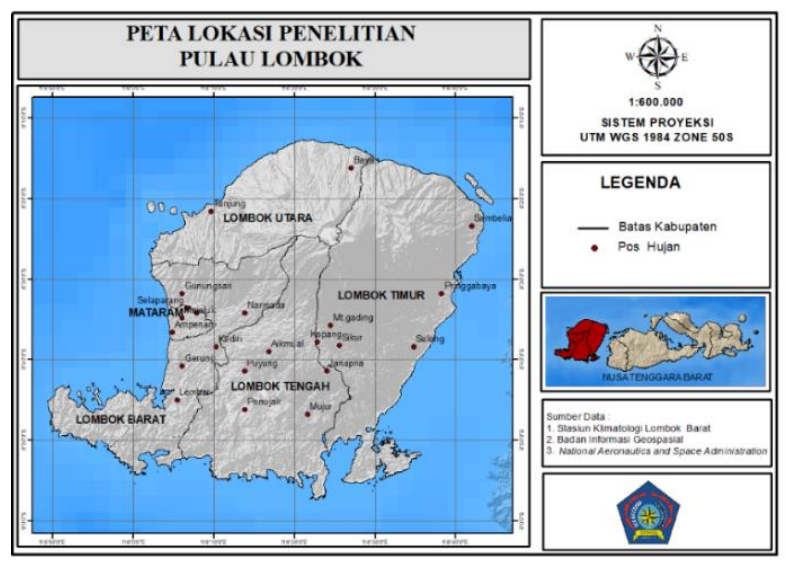

Gambar 1. Lokasi Penelitian

Data yang digunakan untuk penelitian ini adalah sebagai berikut.

a) Data curah hujan pengamatan bulanan selama periode tahun 2001 s.d. 2018. Data tersebut bersumber dari 22 pos hujan di Pulau Lombok dengan kelengkapan data mencapai $100 \%$ dan diperoleh dari Stasiun Klimatologi Lombok Barat.

Tabel 2. Nama dan lokasi pos hujan

\begin{tabular}{cccccccc}
\hline No & Pos Hujan & Lintang & Bujur & No & Pas Hujan & Lintang & Bujur \\
\hline 1 & Lembar & $-8,75$ & 116,09 & 12 & Mt. Gading & $-8,59$ & 116,40 \\
2 & Puyung & $-8,69$ & 116,23 & 13 & Kopang & $-8,63$ & 116,38 \\
3 & Penujak & $-8,77$ & 116,23 & 14 & Janapria & $-8,69$ & 116,40 \\
4 & Aikmul & $-8,65$ & 116,28 & 15 & Mujur & $-8,78$ & 116,36 \\
5 & Narmada & $-8,57$ & 116,23 & 16 & Ampenan & $-8,61$ & 116,08 \\
6 & Kediri & $-8,64$ & 116,17 & 17 & Cakranegara & $-8,57$ & 116,13 \\
7 & Majeluk & $-8,58$ & 116,10 & 18 & Sambelia & -8.39 & 116,70 \\
8 & Gunungsari & $-8,53$ & 116,10 & 19 & Selong & $-8,64$ & 116,58 \\
9 & Gerung & $-8,68$ & 116,10 & 20 & Pringgabaya & $-8,35$ & 116,63 \\
10 & Tanjung & $-8,36$ & 116,16 & 21 & Sikur & $-8,63$ & 116,42 \\
11 & Bayan & $-8,27$ & 116,45 & 22 & Selaparang & $-8,56$ & 116,11 \\
\hline
\end{tabular}

b) Data reanalisis curah hujan bulanan CHIRPS selama periode tahun 2001 s.d. 2018 dengan grid $115,5-119,5^{\circ}$ BT dan $8-9^{\circ}$ LS. Data tersebut diperoleh dari International Research Institute for Climate and Society (IRI) yang didirikan oleh Columbia University dan bekerjasama dengan National Oceanic and Atmospheric 
Administration (NOAA). Data CHIRPS dapat diunduh melalui laman dengan alamat

https://iridl.ldeo.columbia.edu/SOURCES/.UCSB/.CHIRPS/.v2p0/.monthly/.glob al/.precipitation/.

c) Data indeks tutupan lahan NDVI selama periode tahun 2001 s.d. 2018 dengan grid $115,5-116,5^{\circ} \mathrm{BT}$ dan $8-9^{\circ} \mathrm{LS}$ serta memiliki resolusi $0,05^{\circ} \mathrm{x} 0,05^{\circ}$. Data tersebut diunduh dari laman Giovanni milik NASA Earth Observation dengan alamat https://giovanni.gsfc.nasa.gov/giovanni/ndvi.

\subsection{Metode Penelitian}

Langkah penelitian yang pertama kali dilakukan adalah mengumpulkan data yang akan digunakan selama penelitian, yaitu meliputi data reanalisis curah hujan bulanan CHIRPS, data curah hujan pengamatan bulanan, dan data indeks tutupan lahan NDVI. Ketiga data tersebut selama periode tahun 2001 s.d. 2018.

Kemudian, SPI dihitung untuk setiap pos pengamatan hujan menggunakan perangkat lunak $R$-Statistic dengan masukan variabel berupa data reanalisis curah hujan bulanan CHIRPS. Pengolahan indeks SPI dibagi menjadi tiga kriteria, yaitu 1 bulanan $\left(\mathrm{SPI}_{1}\right), 3$ bulanan $\left(\mathrm{SPI}_{3}\right)$, dan 6 bulanan $\left(\mathrm{SPI}_{6}\right)$. Hal ini dimaksudkan agar keterkaitan antara SPI dengan curah hujan observasi dan NDVI dapat diteliti dengan skala waktu yang berbeda, sehingga menjadi masukan yang lebih bervariatif dan meyakinkan.

Setelah itu, korelasi dan signifikansi dihitung untuk ketiga indeks SPI ( $\mathrm{SPI}_{1}, \mathrm{SPI}_{3}$, dan $\mathrm{SPI}_{6}$ ) dengan curah hujan observasi serta NDVI untuk setiap pos pengamatan hujan. Hal ini bertujuan sebagai validasi dari perhitungan ketiga indeks SPI yang telah diperoleh pada langkah sebelumnya.

Korelasi SPI dengan curah hujan dan NDVI dihitung menggunakan Korelasi Pearson karena variabel yang tersedia (SPI dan NDVI) merupakan data distribusi normal, kontinu, dan bukan data kategorikal. Adapun formula Korelasi Pearson disajikan sebagai berikut (Sudjana, 1996).

$$
r_{x y}=\frac{n \sum X Y-\left(\sum X\right)\left(\sum Y\right)}{\left.\left.\left(\sqrt{n \sum\left(X^{2}\right.}\right)\right)-\left(\sum X\right)^{2}\right)\left(n \sum\left(Y^{2}\right)-\left(\sum Y\right)^{2}\right)}
$$

Keterangan:

$r_{x y}:$ korelasi antara variabel $\mathrm{X}$ dan $\mathrm{Y}$,

$n$ : banyak data,

$X \quad$ : variabel satu (curah hujan, SPI, atau SPEI) 
$Y \quad$ : variabel dua (SVI)

Interpretasi nilai koefisien korelasi (r) yang didapatkan pada penelitian ini disajikan pada tabel berikut ini.

Tabel 3. Interpretasi nilai koefisien korelasi

\begin{tabular}{cc}
\hline Nilai $\mathbf{r}$ & Interpretasi \\
\hline 0 & Tidak berkolerasi \\
$0,01-0,20$ & Korelasi sangat rendah \\
$0,21-0,40$ & Rendah \\
$0,41-0,60$ & Agak rendah \\
$0,61-0,80$ & Cukup \\
$0,81-0,99$ & Tinggi \\
1 & Sangat tinggi \\
\hline
\end{tabular}

Sumber: Wijayanto, 2008

Selanjutnya, signifikansi SPI dengan curah hujan dan NDVI dihitung menggunakan rumus sebagai berikut (Sudjana, 1996).

$$
t_{\text {hitung }}=\frac{r \sqrt{n-2}}{\sqrt{1-r^{2}}}
$$

Keterangan:

$t_{\text {hitung }}:$ koefisien signifikansi

$r \quad$ : koefisien Korelasi Pearson

n : banyaknya data

Kemudian untuk menentukan $t_{\text {tabel }}$ memerlukan tingkat signifikansi dan degree of freedom (df) yang ditentukan dari jumlah data (n) dikurangi jumlah variabel (k). Kriteria signifikansi berdasarkan $t_{\text {hitung }}$ dan $t_{\text {tabel }}$ adalah sebagai berikut.

$$
\begin{gathered}
t_{\text {hitung }}>t_{\text {tabel }}=H_{0} \text { ditolak } \\
t_{\text {hitung }}<t_{\text {tabel }}=H_{0} \text { diterima }
\end{gathered}
$$

Parameter $H_{0}$ berarti hipotesis awal yang menyatakan tidak ada hubungan diantara dua variabel, yang dalam penelitian ini penulis menguji keterkaitan antara SPI dengan curah hujan. Pada penelitian ini penulis menggunakan taraf signifikansi $95 \%$.

\section{Hasil dan Pembahasan}

Berikut ini dijelaskan secara rinci hasil dan pembahasan berdasarkan pengolahan data yang telah dilakukan. 


\subsection{Keterkaitan SPI dengan curah hujan observasi}

Berdasarkan pengolahan data yang telah dilakukan, rata-rata korelasi SPI dengan curah hujan observasi bernilai positif dan signifikan. Secara detail hasil korelasi untuk setiap pos hujan disajikan pada Gambar 2 berikut ini.

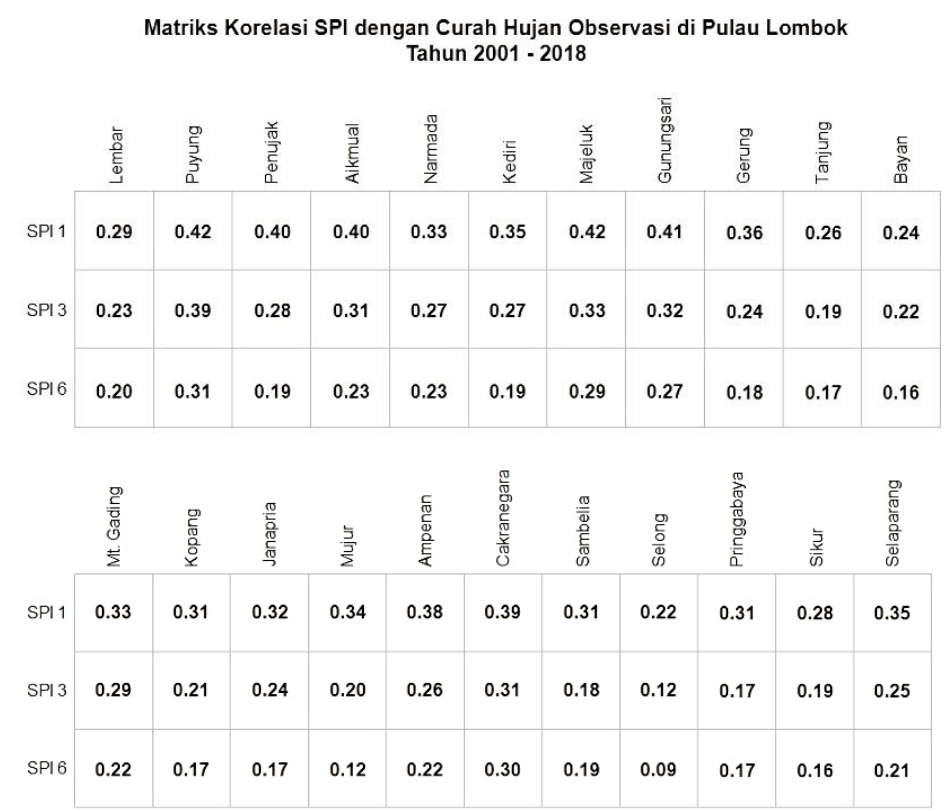

Gambar 2. Matriks korelasi pearson antara SPI dengan curah hujan observasi

Korelasi SPI dan curah hujan observasi (Gambar 2) memiliki nilai rata-rata sebesar 0,31 dengan p-value $<0,05$. Hal ini menunjukkan bahwa kekeringan dengan data curah hujan reanalisis yang dalam penelitian ini menggunakan SPI, dapat menggambarkan kekeringan sebenarnya dalam katagori rendah (Tabel 3). Korelasi tertinggi terdapat di pos hujan Puyung, Kabupaten Lombok Tengah dengan nilai korelasi SPI1, SPI3, dan SPI6 secara berurutan yaitu 0,42; 0.39; dan 0,31. Sedangkan korelasi terendah SPI1, SPI3, dan SPI6 terdapat di pos hujan Selong, Kabupaten Lombok Timur dengan nilai korelasi secara berurutan yaitu 0,$22 ; 0,12$; dan 0,09 .

Indeks kekeringan SPI berkorelasi positif dan signifikan dengan curah hujan observasi. Artinya, kekeringan meteorologis berdasarkan data reanalisis dapat menggabarkan kekeringan meteorologis observasi di wilayah Lombok. Hal ini relevan dengan penelitian Zhao, dkk., (2018) yang menyatakan bahwa SPI dengan data reanalisis berkorelasi positif dengan curah hujan observasi. Jiang, dkk., (2017) dalam penelitiannya juga menyatakan bahwa data reanalisis dapat menggambarkan kekeringan di wilayah Sungai Weihe, Cina. Selain itu, Yan, dkk., (2018) mengemukakan bahwa data curah 
hujan reanalisis berbanding lurus dengan SPI yang menggunakan curah hujan observasi di 118 stasiun meteorologi wilayah Cina Barat Daya pada tahun 1998 - 2013. Tao, dkk., (2016) menyatakan bahwa SPI dengan inputan curah hujan reanalisis dapat menggambarkan frekuensi dan intensitas kekeringan dengan sangat baik di wilayah Provinsi Jiangsu, Cina

Namun, terdapat perbedaan hasil yang ditemukan yaitu, dalam penelitian ini SPI dengan inputan data CHIRPS berkorelasi rendah dengan curah hujan observasi. Sedangkan, SPI dengan inputan TRMM berkorelasi tinggi dengan nilai 0,91. Hal ini dapat disebabkan oleh metode penginderaan jarak jauh dan reanalisis data curah hujan yang dilakukan. Selain itu, kerapatan pos pengamatan curah hujan observasi dan ketersediaan data dari kedua wilayah penelitian ini juga berbeda. Nilai korelasi untuk setiap pos hujan (Gambar 2) akan semakin rendah seiring dengan durasi kekeringan yang lebih panjang. Dapat dilihat pada Gambar 2 jika nilai korelasi SPI1 dengan curah hujan observasi untuk seluruh pos hujan secara umum bernilai lebih tinggi dibandingkan dengan SPI3 dan SPI6 secara berurutan. Hasil ini sejalan dengan penelitian Zhao, dkk., (2018) bahwa SPI skala lebih kecil memiliki nilai korelasi lebih tinggi dengan curah hujan observasi. Hal ini dikarenakan semakin lama durasi kekeringan, dibutuhkan juga inputan curah hujan yang lebih banyak, sehingga bias atau error dari data hujan CHIRPS yang digunakan juga akan semakin besar terhadap data observasinya.

\subsection{Keterkaitan SPI dengan NDVI}

Nilai korelasi untuk setiap pos hujan disajikan pada Gambar 3 berikut ini.

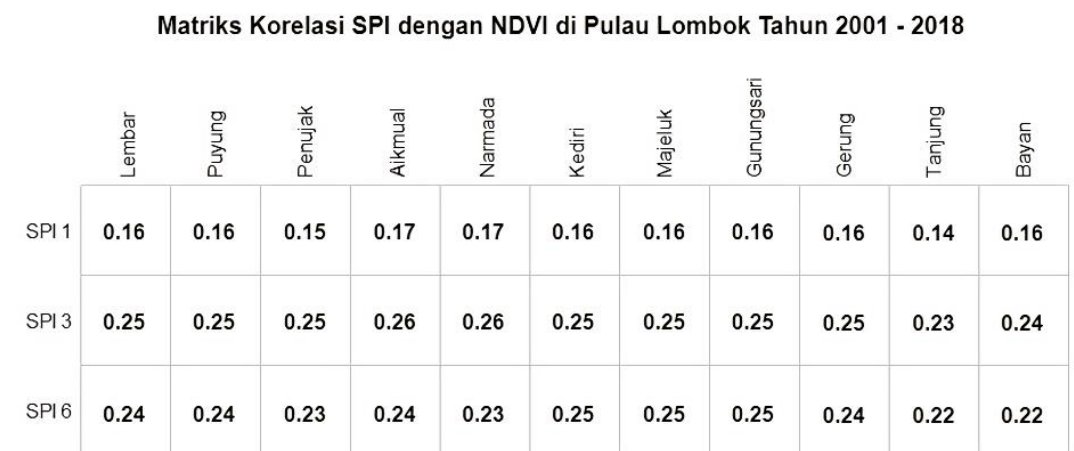




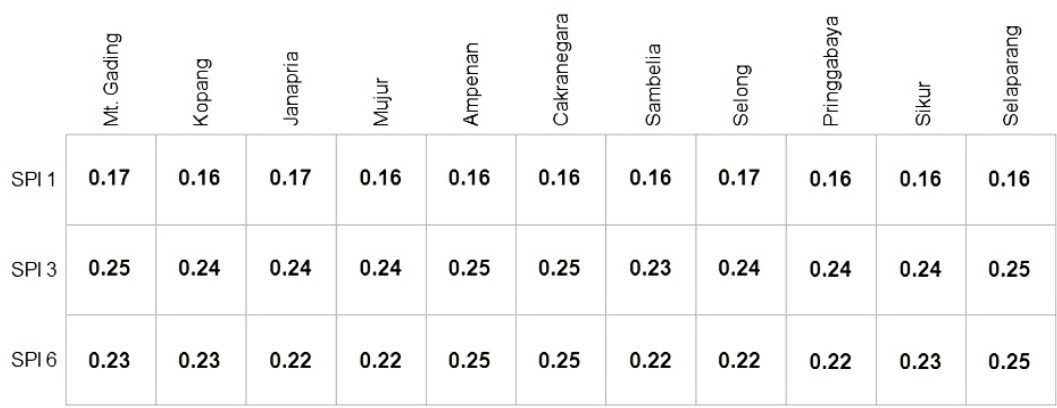

Gambar 3. Matriks korelasi pearson antara SPI dengan NDVI

Nilai korelasi SPI dengan NDVI menunjukkan bahwa rata-rata korelasi antarkedua indeks ini sebesar 0,21 (rendah) dengan $p$-value $<0,05$. Walau memiliki keterkaitan yang rendah (Tabel 3), namun dapat dinyatakan bahwa kekeringan meteorologis yang terjadi di wilayah Lombok dapat mempengaruhi kekeringan agrikultural selama periode 2001 - 2018. Secara umum, nilai korelasi $\mathrm{SPI}_{3}$ lebih tinggi dibandingkan dengan SPI1 maupun $\mathrm{SPI}_{6}$ (Gambar 3). Korelasi tertinggi terjadi di pos hujan Aikmual sebesar 0,26 (SPI1), Narmada sebesar 0.26 (SPI3), dan Cakranegara 0,25 (SPI6). Sedangkan korelasi terendah terjadi di pos hujan Tanjung untuk SPI1 dan SPI3 sebesar 0,14 dan 0,23; serta pos hujan Janapria sebesar 0,23 (SPI6).

Korelasi tertinggi berada di pos hujan Aikmual sebesar 0,26 dengan p-value < 0,05. Hal ini menunjukkan jika kekeringan meteorologis berbanding lurus dengan kekeringan agroklimatologi. Hasil dari penelitian ini sejalan dengan penelitian Jain, dkk., (2010) yang menyatakan bahwa kekeringan akibat defisit curah hujan (kekeringan meterologis) berpengaruh terhadap kondisi vegetasi di wilayah Rajasthan, India. Penelitian Dutta, dkk., (2013) juga memiliki hasil bahwa $\mathrm{SPI}_{3}$ berkorelasi lebih tinggi dengan NDVI dibandingkan dengan $\mathrm{SPI}_{1}, \mathrm{SPI}_{6}$, dan $\mathrm{SPI}_{12}$ di wilayah Rajasthan Timur, India. Namun, sedikit berbeda dengan hasil penelitian Jain, dkk., (2010) bahwa SPI 6 memiliki nilai korelasi tertinggi dengan NDVI sebesar 0,56 dibandingan dengan $\mathrm{SPI}_{1}$ $(0,33)$ dan $\mathrm{SPI}_{3}(0,53)$ di wilayah Rajasthan India. Hal ini dikarenakan perbedaan karakteristik local baik kondisi geografis maupun vegetasi di masing-masing wilayah penelitian. Selain itu, kebutuhan air tanaman bervariasi tergantung jenis serta tahap pertumbuhannya (Ji dan Peters, 2003).

Semakin lama durasi kekeringan, semakin tinggi nilai korelasinya terhadap NDVI, dengan masa toleransi tanaman terhadap ketersediaan air tanah selama 3 bulan yang dibuktikan dengan nilai korelasi $\mathrm{SPI}_{3}$ lebih tinggi dibandingkan yang lainnya. Menurut Ji dan Peters (2003), dalam penelitiannya menyatakan bahwa $\mathrm{SPI}_{3}$ berpengaruh 
lebih signifikan terhadap kekeringan agrikultural di wilayah Amerika Tengah. Hal ini menunjukkan bahwa dampak presipitasi terhadap vegetasi tidak terjadi secara instan, tetapi bersifat kumulatif. Pada penelitian ini, curah hujan yang terjadi dalam 1 bulan tidak terlalu mempengaruhi vegetasi pada bulan tersebut, tetapi respon vegetasi cukup signifikan selama periode tersebut. Nilai korelasi $\mathrm{SPI}_{3}$ yang lebih tinggi juga menggambarkan bahwa tanah di wilayah Lombok memiliki kelembaban yang cukup sehigga dapat mencukupi kebutuhan air tanaman ketika terjadi kekeringan (defisit air hujan) hingga 3 bulan lamanya. Menurut Zuo, dkk., (2019), nilai korelasi rendah antara SPI dengan NDVI adalah hal yang wajar. Hal ini dikarenakan SPI hanya menggunakan curah hujan sebagai inputan utama, sedangkan dalam kenyataannya, pertumbuhan tanaman tidak hanya dipengaruhi oleh curah hujan, melainkan juga dipengaruhi oleh penyinaran matahari, suhu, evapotranspirasi, dan lain sebagainya.

\section{Kesimpulan}

Berdasarkan pengolahan data dan analisis yang telah dilakukan, dapat disimpulkan bahwa SPI berbasis data reanalisis CHIRPS rata-rata berkorelasi positif dan signifikan terhadap curah hujan observasi sebesar 0,31 dengan p-value $<0,05$ dikarenakan perbedaan metode dan fasilitas pengambilan data curah hujan. Indeks yang memiliki korelasi tertinggi dengan curah hujan observasi adalah SPI1. Sedangkan, nilai korelasi SPI dan NDVI sebesar 0,21 serta p-value < 0,05, dengan korelasi tertinggi yaitu SPI3. Kekeringan meteorologis terbukti dapat mempengaruhi kekeringan agrikultural di wilayah Lombok selama periode tahun 2001 - 2018. Lebih lanjut, diperlukan metode untuk mengoreksi data curah hujan CHIRPS atau data penginderaan jarak jauh terhadap data observasi sehingga hasilnya lebih baik dan dapat dibangun model untuk prediksi kekeringan. Sebagai bahan masukan untuk penelitian selanjutnya, dapat menjadikan parameter suhu, angin, penyinaran matahari, dan unsur meteorologis lainnya sebagai input monitoring kekeringan meteorologis yang berdampak pada kekeringan agrikultural.

\section{Pustaka}

Badan Nasional Penanggulangan Bencana. (2015). Kajian Risiko Bencana Nusa Tenggara Barat 2016 - 2020. Badan Nasional Penanggulangan Bencana, Jakarta. 51

Badan Nasional Penanggulangan Bencana, Sejarah Bencana Kekeringan Pulau Lombok, http://bnpb.cloud/dibi/tabel2a, Diakses pada 7 Juni 2020.

Christiawan, P. I., Atmaja, D. M., \& Citra, I. P. A. (2020). Inventarisir Risiko Bencana 
Kekeringan Di Desa Selat. Proceeding Senadimas Undiksha, 211.

Dutta, D., Kundu, A., \& Patel, N. R. (2013). Predicting agricultural drought in eastern Rajasthan of India using NDVI and standardized precipitation index. Geocarto International, 28(3), 192-209.

Funk, C. C., Peterson, P. J., Landsfeld, M. F., Pedreros, D. H., Verdin, J. P., Rowland, J. D., ... \& Verdin, A. P. (2014). A quasi-global precipitation time series for drought monitoring. US Geological Survey data series, 832(4), 1-12. http://iridl.ldeo.columbia.edu/SOURCES/.UCSB/.CHIRPS/.v2p0/.monthly/.global /.precipitation/. Diakses pada 01 Mei 2020

Giovanni The Bridge Between Data and Science, Data, National Aeronautics and Space Administration, https://giovanni.gsfc.nasa.gov/giovanni/, Diakses pada 23 September 2020.

Jain, S. K., Keshri, R., Goswami, A., \& Sarkar, A. (2010). Application of meteorological and vegetation indices for evaluation of drought impact: a case study for Rajasthan, India. Natural hazards, 54(3), 643-656.

Jiang, S., Ren, L., Zhou, M., Yong, B., Zhang, Y., \& Ma, M. (2017). Drought monitoring and reliability evaluation of the latest TMPA precipitation data in the Weihe River Basin, Northwest China. Journal of Arid Land, 9(2), 256-269.

Ji, L., \& Peters, A. J. (2003). Assessing vegetation response to drought in the northern Great Plains using vegetation and drought indices. Remote Sensing of Environment, 87(1), 85-98.

Lado, I. A. (2017). Monitoring Zona Kekeringan Meteorologi Dengan Memanfaatkan Sig. Malang

Lillesand, T. M., Kiefer, R. W., \& Chipman, J. (1987). Remote sensing and image processing.

McKee, T. B., Doesken, N. J., \& Kleist, J. (1993). The relationship of drought frequency and duration to time scales. In Proceedings of the 8th Conference on Applied Climatology (Vol. 17, No. 22, pp. 179-183).

Sudjana, N. (1996). Statistik Dasar, Tarsito, Bandung

Surmaini, E. (2016). Pemantauan dan peringatan dini kekeringan pertanian di Indonesia.

Tao, H., Fischer, T., Zeng, Y., \& Fraedrich, K. (2016). Evaluation of TRMM 3B43 precipitation data for drought monitoring in Jiangsu Province, China. Water, $8(6)$, 221.

Wijayanto, A., (2008), Analisis Korelasi Pearson Product Moment.

Wilhite, D. A., \& Glantz, M. H. (1985). Understanding: the drought phenomenon: the role of definitions. Water international, 10(3), 111-120. 
Yan, G., Liu, Y., \& Chen, X. (2018). Evaluating satellite-based precipitation products in monitoring drought events in southwest China. International Journal of Remote Sensing, 39(10), 3186-3214.

Yasin, I., Ma'shum, M., Abawi, Y. dan Hadiahwaty, L., 2004, Penggunaan Indeks Osilasi Selatan untuk Memprakirakan Sifat Hujan Musiman Guna Menentukan Strategi Tanaman di Lahan Tadah Hujan Di Pulau Lombok. Jurnal Agromet Indonesia, Vol. 18.

Zhao, Q., Chen, Q., Jiao, M., Wu, P., Gao, X., Ma, M., \& Hong, Y. (2018). The temporalspatial characteristics of drought in the Loess Plateau using the remote-sensed TRMM precipitation data from 1998 to 2014. Remote Sensing, 10(6), 838.

Zuo, D., Cai, S., Xu, Z., Peng, D., Kan, G., Sun, W., ... \& Yang, H. (2019). Assessment of meteorological and agricultural droughts using in-situ observations and remote sensing data. Agricultural Water Management, 222, 125-138 